Available online at

INSECTA

Integrative Science Education and Teaching Activity Journal

Journal homepage : https://jurnal.iainponorogo.ac.id/index.php/insecta

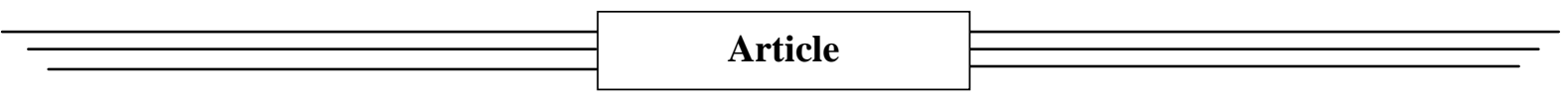

\title{
Application of Inquiry Based Learning Model Using STEM Approach to Reduce Students' Intrinsic Cognitive Load
}

\author{
Rita Sundari ${ }^{1}$, Omnia Salah Ahmed ${ }^{2}$, Abdurrahman $^{3}$, Kartini Herlina $^{4 *}$ \\ ${ }^{1}$ Department of Physics Education, University of Lampung, Indonesia \\ ${ }^{2}$ Member of The Egyptian Minister's of Education Technical Office, Egypt \\ ${ }^{3}$ Department of Physics Education, University of Lampung, Indonesia \\ ${ }^{4}$ Department of Physics Education, University of Lampung, Indonesia \\ *Corresponding Address: kartini.herlina@fkip.unila.ac.id
}

\section{Article Info}

Article history:

Received: March 25, 2021

Accepted: April 27, 2021

Published: May 31, 2021

\section{Keywords:}

Cognitive Load;

Intrinsic Cognitive Load

(ICL);

STEM

\begin{abstract}
This study is an experimental research using a quasi-experimental design with the type of non-equivalent control group pretest-posttest. This research aims to reduce Intrinsic Cognitive Load (ICL) through Inquiry Based Learning (IBL) model base STEM approach. This research was conducted at SMA Negeri 1 Seputih Banyak with the research subjects of class X IPA 1 students and X IPA 4. Data Intrinsic Cognitive Load obtained from essay the pretest-posttest (Task Complexity worksheet). Cognitive load test data analysis was performed using the data normality test, $\mathrm{N}$-gain test and hypothesis test using the Paired Sample T-Test. The experimental class implements the Inquiry Based Learning model based audio and visual using STEM approach while the control class is nonaudio and visual. The results showed by the average value of N-Gain Intrinsic Cognitive Load (ICL) in the experimental class was 0.63 with the moderate category and the control class was 0.18 with the low category. Based on data analysis, can be concluded that there is a positive influence in the form of a decrease in the cognitive load Intrinsic Cognitive Load (ICL) in the experimental class using the Inquiry Based Learning model plus an audio and visual based STEM approach.
\end{abstract}

\section{INTRODUCTION}

Changes in the learning system as an effort to realize the expectations in education, led the Minister of National Education to initiate the Full Day School. Full Day School is an education system that implements a full day of learning in schools, namely learning that starts from morning to early evening (Hilalah, 2009). The Full Day School system is expected to be able to increase student knowledge an alternative to complete the demands of education in the present. However, based on the results of interviews with high school teachers in 4 districts in Lampung, it is known that there are still many schools that implement full day schools. The implementation of Full Day School makes students stay at school all day and that causes the 
reduction of rest time and can cause the students become more cognitively tired (Baharun \& Alawiyah, 2018). Students who are cognitively tired are only able to store and absorb a little information so that students feel difficult in learning and will cause a cognitive load on students (Sweller et al; 2011).

Cognitive load theory states that the cognitive load in a caused by many demands of the task so that it will exceed the working memory capacity (Sweller, 1998). Cognitive load can be reduced by motivating the students. A better way to motivate the students is to use inductive learning that present phenomena, where the teacher begins by giving the students specific challenges such as experimental data to interpret, etc. Students solve challenges by recognizing how to solve problems using facts, skills and conceptual understanding, where the teacher will provide instruction or help students to learn independently (Bransford, Brown \& Cocking; 2000).

Inductive learning methods have various forms of learning methods, one of which is inquiry-based learning. Several researchers have tested this learning method in a group. student-centered learning model that can be used to reduce cognitive load and motivate students is the Inquiry Based Learning model (Savignon, 2007). The IBL learning model trains students not only to learn by listening to the teacher lecture, but also learn the students while doing experiments. Therefore students will get used to analyzing experimental data, discussing with their groups and other students, communicating an invention, and working independently (Wenning, 2011). A student-centered learning approach is a teaching practice that can improve student performance and encourage positive learning, namely the results of student attitudes in science, technology, engineering and mathematics (STEM) (Freeman et al; 2014).

The current Covid-19 pandemic requires learning to be done online (Collins, 2002). Online learning is conveyed through audio and visuals such as pictures and videos that motivate students to learn and make students happy till reduce their cognitive load. This is in accordance with the learning theory of Mayer and Moreno (2003) that a complementary combination of verbal and visual aspects is needed in multimedia learning which aims to facilitate cognitive processes. Garnasih, Hidayat, \& Rahmat (2015) has attest that learning using audio and visuals can reduce students' cognitive load. Based on an interview with one of the physics teachers and seeing the problems faced by the teacher and the ability of media that will be used to support the course of the research. So, in this research, using the IBL learning model with the STEM approach audio and visual based learning is designed aimed at reducing student cognitive load in SMA Negeri 1 Seputih Banyak.

\section{METHODS}

This research was conducted on April 24, 2020 for one month. The place where this research was carried was SMA Negeri 1 Seputih Banyak. The research was conducted using two samples that is class X IPA 1 and X IPA 4 with purposive sampling technique. The data in this quasi-experimental were obtained from three data collection methods, namely the Questionnaire, and the Interview. The research hypothesis is:

Ho: There is no effect of the application of the IBL model using a STEM approach to cognitive load.

Ha: There is an effect of the application of the IBL model using a STEM approach to cognitive load.

Hypothesis Test using the Paired Sample T-Test. 


\section{RESULTS AND DISCUSSION}

Based on the results of research conducted at SMA Negeri 1 Seputih Banyak, Central Lampung Regency, with sample of 53 students in total. The results of the normality test in this research can be seen in Table 1 .

Table 1. The Results data of Intrinsic Cognitive Load (ICL) Normality Test

\begin{tabular}{ccccc}
\hline \multirow{2}{*}{ Parameter } & \multicolumn{2}{c}{ Experiment } & \multicolumn{2}{c}{ Control } \\
\cline { 2 - 5 } & $\begin{array}{l}\text { Pretest } \\
\text { ICL }\end{array}$ & $\begin{array}{l}\text { Posttest } \\
\text { ICL }\end{array}$ & $\begin{array}{l}\text { Pretest } \\
\text { ICL }\end{array}$ & $\begin{array}{l}\text { Posttest } \\
\text { ICL }\end{array}$ \\
\hline $\begin{array}{c}\text { Sig. (2- } \\
\text { tailed) }\end{array}$ & 0,200 & 0,200 & 0,200 & 0,091 \\
\hline
\end{tabular}

Based on data in normality of Intrinsic Cognitive Load (ICL), it is known that the significance value before and after in the experimental and control classes is $>0.05$, so Ho is accepted. It means that the sample comes from a normally distributed population. The results of the ICL homogeneity test in this study can be seen in Table 2 .

Table 2. The Results of ICL Homogeneity Test

\begin{tabular}{rrrrrr}
\multicolumn{5}{c}{ Test of Homogeneity of Variances } \\
HASIL & & \\
Levene Statistic & $d f 1$ & & $d f 2$ & Sig. \\
2.156 & & 3 & & 100 & .098 \\
\hline
\end{tabular}

Based on the ICL homogeneity data in Table 2, the significance value of Intrinsic Cognitive Load in the experimental class and control class is $>0.05$, then Ho is accepted, meaning that the $\mathrm{N}$-gain in the experimental class and control class has the same or homogeneous variance. The results of the Paired Sample T-Test ICL can be seen in Table 3.

Table 3. The results of Intrinsic Cognitive Load (ICL) paired sample T-Test Hypothesis

\begin{tabular}{|c|c|c|c|c|}
\hline & & Mean & $\begin{array}{c}\text { Std. } \\
\text { Deviation }\end{array}$ & Sig. (2-tailed) \\
\hline Pair 1 & $\begin{array}{l}\text { Pretest } \\
\text { Experiment } \\
\text { Posttest } \\
\text { Experiment }\end{array}$ & $40.04000^{-}$ & 4.03609 & .000 \\
\hline Pair 2 & $\begin{array}{l}\text { Pretest Control - } \\
\text { Posttest Control }\end{array}$ & $\begin{array}{r}- \\
13.70370\end{array}$ & 8.64165 & .000 \\
\hline
\end{tabular}

Based on Table 3 shows the Sig. (2-tailed) the analysis results of the Paired Sample TTest in the experimental class and control class $\leq 0.05$, then $\mathrm{H} 0$ is rejected or $\mathrm{H} 1$ is accepted. It means, there are differences in Intrinsic Cognitive Load before and after learning using the IBL model with an audio and visual-based STEM approach in the experimental class and there are differences in Intrinsic Cognitive Load before and after learning using the IBL model based STEM approach with no audio and visual in the control class. The results of the Extraneous Cognitive Load N-gain in the experimental and control classes can be seen in Table 4.

Table 4. The Average Data of Intrinsic Cognitive Load (ICL) N-gain

\begin{tabular}{ccc}
\hline Score Results & Experiment & Control \\
\hline Highest Gain & 46,00 & 42,00 \\
\hline Lowest Gain & 32,00 & 3,00 \\
\hline Average Gain & 40,04 & 13,70 \\
\hline The Average Increase Score & $40 \%$ & $13 \%$ \\
\hline Average N-Gain & 0,63 & 0,18 \\
\hline Average N-Gain Category & Moderate & Low
\end{tabular}


Based on Table 4, it is known that the $\mathrm{N}$-gain average of the experimental class is higher than the control class. The results of the N-gain Intrinsic Cognitive Load (ICL) in the experimental class are in the moderate category.

Based on the data from the results of the Intrinsic Cognitive Load (ICL) hypothesis using the Paired Sample T-Test in the experimental class and the control class, the significance value is less than 0.05 , so it is known that there are differences in Intrinsic Cognitive Load (ICL) before and after learning in experimental class and control class. The test results can also be seen with the $\mathrm{N}$-gain value in the experimental class and control class which obtained an average N-gain Intrinsic Cognitive Load (ICL) of 0.63 in the moderate category and the average $\mathrm{N}$-gain in the control class is 0.18 in the low category. It shows that the increase in Intrinsic Cognitive Load (ICL) in the experimental class is higher than the increase in Intrinsic Cognitive Load (ICL) in the control class. The results of the average Ngain Intrinsic Cognitive Load (ICL) in the experimental class and control class can be seen in Figure 1 which is presented in the form of a bar chart.

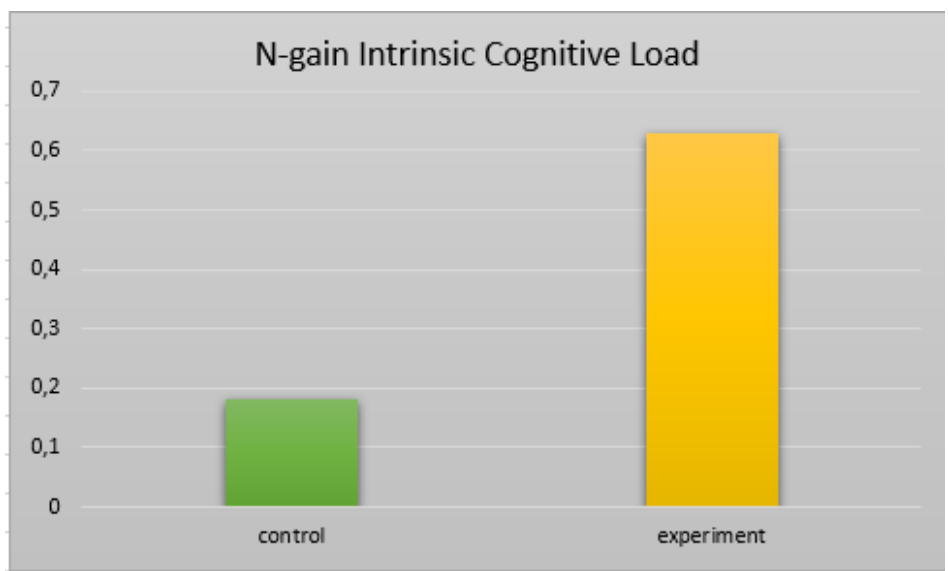

Figure 1. N-gain Intrinsic Cognitive Load (ICL).

The percentage of N-gain Intrinsic Cognitive Load (ICL) based on the low, moderate, and high categories using 25 students in the experimental class and 27 students in the control class. The results of the N-gain ICL proportion can be seen in Figure 2.

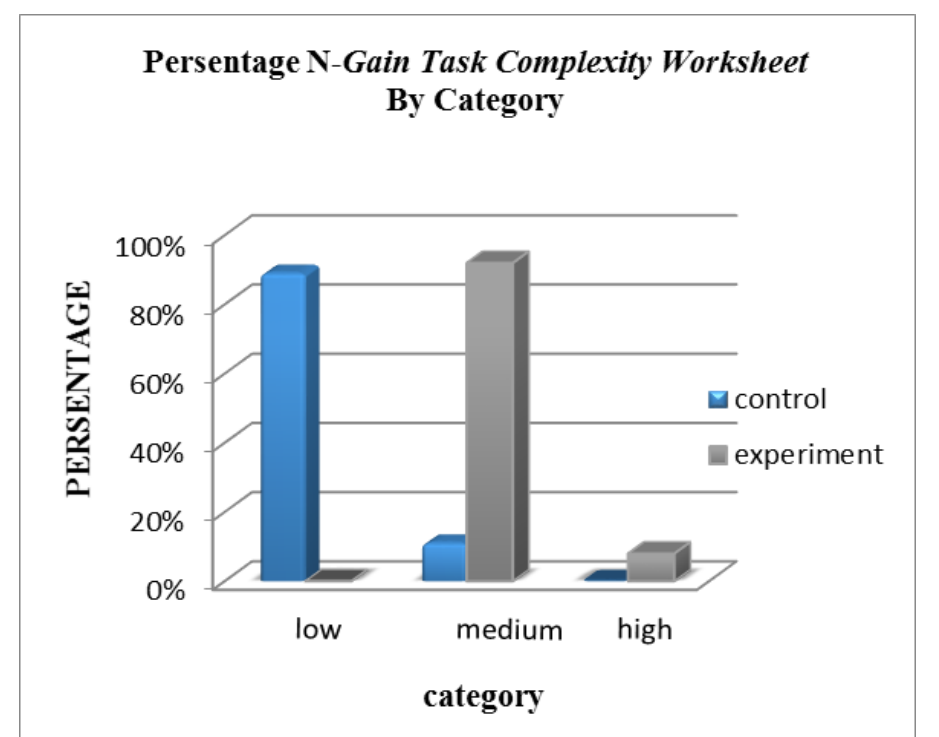

Figure 2. Persentage N-Gain Task Complexity Worksheet By Category 
Based on the data in Figure 2, the percentage results in the experimental class using the IBL Model with an audio and visual based STEM approach experienced an increase in ICL in the high category by $8.00 \%$, while in the control class using the same model and approach but not using audio and visual is $0.00 \%$. The increase in ICL in the moderate category experienced an enhancement in the experimental class which was $92 \%$, while in the control class it was $11 \%$ of students. Furthermore, the ICL increase in the low category in the control class experienced a high increase of $89.00 \%$. The increase in ICL learning outcomes in the experimental class is because in every lesson on Newton's Law I, II, and III material, students are presented with pictures and videos of daily phenomena in real life. Newton's First Law is prsented a video of a coin placed on a ruler to prove the law of inertia. Newton's Second Law is presented a video of a broke down car being driven by one and three people to prove that mass has an effect on acceleration. Newton's third law is presented in a video of a person riding a gas bicycle, when the gas is sprayed forward the bicycle will move backwards, proving the law of action-reaction. The purpose of providing pictures and videos during learning is to motivate students to learn the Newtonian Law material. Video views to stimulate learning in Newton's First, Second and Third Laws are presented in Figures 3, 4, and 5 , sequentually.

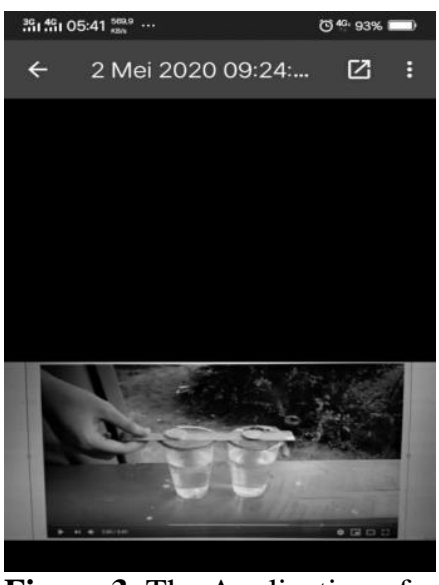

Figure 3. The Application of Newton's $1^{\text {st }}$ Law

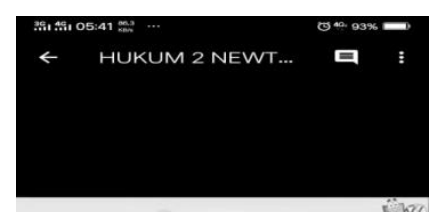

to

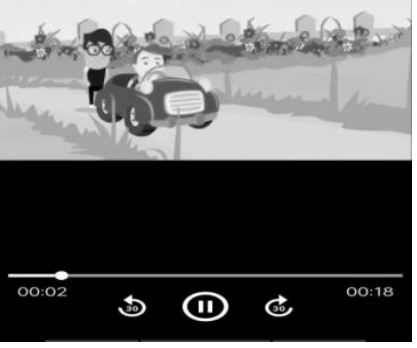

Figure 4. The Application of Newton's $2^{\text {nd }}$ Law

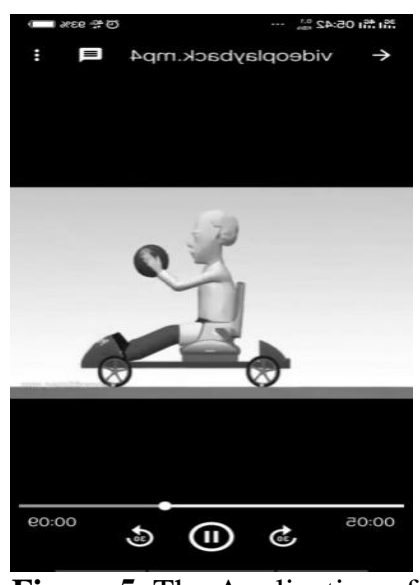

Figure 5. The Application of Newton's $3^{\text {rd }}$ Law

The lesson of Newton's Second Law is carried out practically with the help of the PHeT Simulation application. It is carried out practically using PHeT Simulation in order to attract students' attention to learn, besides that in the PHeT Simulation there is an animation of objects and humans that can be moved by students according to the instructions in the LKPD. Students are asked to predict the acceleration relationship of an object when subjected to varying forces, to make a graph of relation between force and acceleration using Microsoft Excel. By utilizing the PHeT simulation application. Students are asked to simulate a PHeT Simulation, formulate the equation of the relationship between acceleration with mass and force, and students are asked to draw a graph of relation between force and acceleration presented on the LKPD sheet. The appearance of PHeT Simulation is presented in Figure 6. 

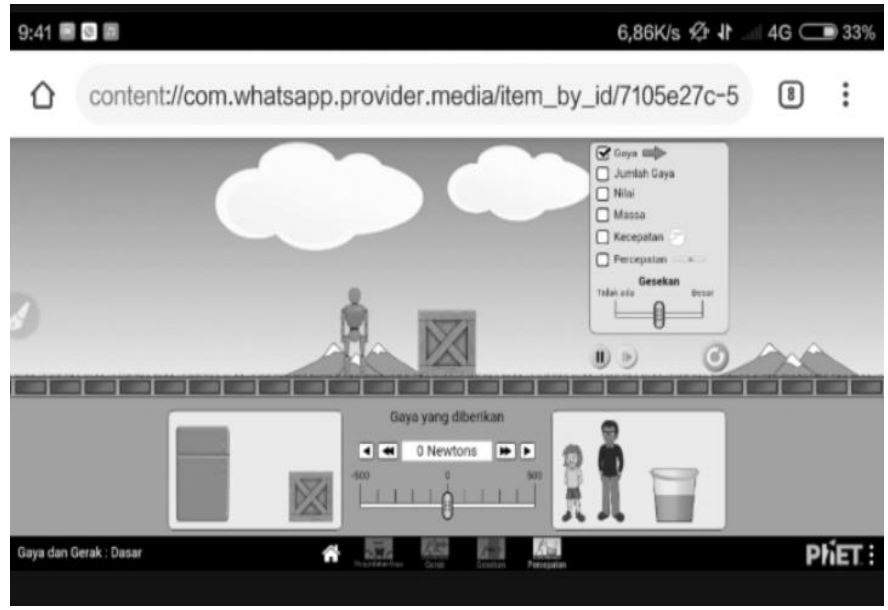

Figure 6. The Display of PHeT Simulatiom

Students have never used the PHeT Simulation application before and this is the first time, so students are curious about the PHeT Simulation application. It makes students happy in learning it and feels not overwhelmed by learning which is usually only presented with formulas. This is supported by interviews with students. The following is the transcript of the results of the researcher interview with X IPA 4 students.

G: assalamualaikum dek, after kakak taught in your class, may kakak ask about the lesson that kakak have given

S: Waalaikumussalam kak rita. Yes kak, of course.

G: What putri think, when kakak give newton's phenomena in daily life, is it make easier to understand the lesson?

S: Of course kak, when kakak gave the phenomena like that, putri has been easier to understand the newton's law subject because the phenomena related to our daily life and putri think, it has never been taught kak.

G: In putri opinion, how is the lesson that presented in the form of picture and video?

$S$ : Most of us like it kak, because it doesn't make us feel bored. Usually the phyisics subject is only about counting, so it make us feel bored and dizzy kak.

G: When practice using PHeT, do you feel dizzy or not?

S: It doesn't make us dizzy kak, because we just first time know about that application, so it make us feel coriuous, hehe.

G: Sorry dek, kakak have permission to ask about learning model using picture and video that has presented in your class. How do you think about it?

S: I think by using picture and video, the lesson is understandable compare to study system before

G: Do you feel bored?

S: I personally don't feel bored kak,because I enjoyed it We can also understand the concept. Moreover added by practice using that new application kak. Before this we have never studied like that.

G: assalamualaikum dek, Mba wanna ask, how do you feel after study with mba?

$S$ : We more understand about the concept mba, before it we feel like don't know about the concept at all.

$G$ : What do you think about the presentation using video and picture dek? 
S: Like it so much mba, study become more enjoyable and not too much burden mba. Before it, we have never been taught about the concept. Only gift the formula, example, then doing the task mba.

Source: (The Students of SMA Negeri 1 Seputih Banyak, 2020)

The results of the ICL were in the form of solving the Task Complexity Worksheet which was presented in visual form. After the students applying the audio and visual based STEM approach, there is an enhancement compared to the application of the STEM approach which was not using audio and visual in learning Newton's Law of motion. It is because the STEM approach does not only study one scientific discipline but applies four disciplines and learning presented in audio and visual forms can facilitate student cognitive processes, so that student learning outcomes can be increased, according to the opinion of Stohlmann, Moore and Roehrig (2012). towards STEM disciplines through social-cultural learning that is relevant to the STEM content can increase interest and achievement in mathematics and science, and the opinion of Mayer \& Moreno (2003) that meaningful learning requires a large number of cognitive processes that take place visually and verbally.

Based on the results of hypothesis test and the theory that has become a reference, there are differences enhancement in learning outcomes of Intrinsic Cognitive Load (ICL) using an audio and visual based STEM approach with classes that are not using audio and visual. This is relevant to Muthi'ik's research, Abdurrahman and Rosidin (2018), which states that the average learning outcomes before and after learning by applying the STEM approach have increased, and Garnasih, Hidayat and Rahmat's (2015) research states that video-based learning on Plant Diversity subject can reduce students' intrinsic cognitive load.

\section{CONCLUSION}

There is an effect of decreasing cognitive load (Intrinsic Cognitive Load) in classrooms that use audio and visuals, namely the greater the results of the task complexity, the lower the student's cognitive load.

\section{REFERENCES}

Baharun, H., \& Alawiyah, S. (2018). Pendidikan Full Day School dalam Perspektif EpSTEMologi Muhammad 'Abid Al-Jabiri. Jurnal Kependidikan Islam, 4(1), 1-22.

Collins, J. (2002). Teaching and Learning with Multimedia. Routledge. doi:10.4324/9780203441305.

Freeman, S., Eddy, S. L., McDonough, M., Smith, M. K., Okoroafor, N., Jordt, H., \& Wenderoth, M. P. (2014). Active Learning Increases Student Performance In Science. Proceedings Of The National Academy Of Science Of The United States Of America, 111 (23), 8410-8415.

Ganarsih, T., Hidayat, T., Rahmat, A. (2015). Menurunkan beban kognitif intrinsic siswa MA dalam pembelajaran klasifikasi spermatophyte menggunakan tayangan video keanekaragaman tumbuhan. In seminar nasional XII pendidikan biologi UNS.

Mayer, R. E., \& Moreno, R. (2003). Nine ways to reduce cognitive load in multimedia learning. Educational Psychologist, 38, 43-52.

Muthi'ik, I.I., Abdurrahman, A., \& Rosidin, U. (2018). The Effectiveness Of Applying STEM Approach To Self-Efficacy And Student Learning Outcomes For Teaching Newton's Law. Jurnal Penelitaian \& Pengembangan Pendidikan Fisika, 4(1), 11-18.

Savignon, Sandra J. (2007). Beyond Communicated Language Teaching. Journal of Fragmatics 39 (1): 207-220. 
Stholman, M., Moore, T. J., \& Roehrig, G.H. (2012). Considerations For Teaching Integrated STEM Education. Journal Of Pre-College Engineering Education Research (J-PEER), 2 (1), 4-11.

Sweller, J., Ayres, P. \& Kalyuga, S. (2011). Cognitive Load Theory. New York.. SpringerVerlag: Department Education.

Sweller, J., Merrienboer, J., \& Paas, F. (1998). Cognitive Architecture and Instructional Design. Educational Psychology Review, 10(3), 251-296.

Wenning, C. J. (2011). The levels of inquiry model of science teaching. Journal of Physics Teacher Education Online, 6(2), 9-16. 